\title{
CLINICAL EXPERIENCE IN USING COMBINED FERROTHERAPY WITH L-CARNITINE IN STANDARD TREATMENT OF PATIENTS WITH CHRONIC HEART FAILURE WITH REDUCED LEFT VENTRICLE EJECTION FRACTION WITH CONCOMITANT IRON DEFICIENCY ANEMIA
}

\author{
${ }^{1}$ Professor Valeriy P Ivanov, \\ ${ }^{2}$ Assistant professor Mariia O Kolesnyk, \\ ${ }^{2}$ Associate professor, Oleg N Kolesnyk \\ Ukraine, Vinnytsya, National Pirogov Memorial Medical University, Vinnytsya; \\ ${ }^{1}$ Head of internal medicine department №3; \\ ${ }^{2}$ Department of internal medicine №3
}

\section{DOI: https://doi.org/10.31435/rsglobal_ws/31102019/6718}

\section{ARTICLE INFO \\ Received: 11 August 2019 \\ Accepted: 17 October 2019 \\ Published: 31 October 2019}

\section{KEYWORDS}

chronic heart failure, iron deficiency, iron deficiency anemia, oral ferrotherapy,

L-carnitine.

\begin{abstract}
Chronic heart failure (CHF) is a global public health problem. Despite all the technical advances available in modern cardiology, a medical strategy for the treatment of $\mathrm{CHF}$ has been and remains the main focus of therapeutic intervention. A particular problem is the treatment of CHF with concomitant pathology. The modern pharmacological strategy for the treatment of patients with CHF and iron deficiency anemia, except iron preparations, must take into account the use of agents that have antihypoxic, antioxidant and membrane-stabilizing effects, and at the same time regulatory effect on the metabolism of physiologically active compounds to improve the condition of patients. Therefore, this study is aimed to evaluate the effectiveness of iron deficiency anemia's correction, identify and compare the effect of oral ferrotherapy and combined use of ferrotherapy with L-carnitine on clinical and instrumental parameters of patients with chronic heart failure with reduced ejection fraction of left ventricle as possible variants of additional therapy to standard treatment.
\end{abstract}

Citation: Valeriy P Ivanov, Mariia O Kolesnyk, Oleg N Kolesnyk. (2019) Clinical Experience in Using Combined Ferrotherapy with L-Carnitine in Standard Treatment of Patients with Chronic Heart Failure with Reduced Left Ventricle Ejection Fraction with Concomitant Iron Deficiency Anemia. World Science. 10(50), Vol.1. doi: 10.31435/rsglobal_ws/31102019/6718

Copyright: (C) 2019 Valeriy P Ivanov, Mariia O Kolesnyk, Oleg N Kolesnyk. This is an open-access article distributed under the terms of the Creative Commons Attribution License (CC BY). The use, distribution or reproduction in other forums is permitted, provided the original author(s) or licensor are credited and that the original publication in this journal is cited, in accordance with accepted academic practice. No use, distribution or reproduction is permitted which does not comply with these terms.

Introduction. Chronic heart failure (CHF) with reduced left ventricular (LV) ejection fraction $(E F)$ is a clinical syndrome of dyspnea, exercise intolerance and/or edema resulting from an impairment of ejection of blood, usually documented by a left ventricular ejection fraction of $40 \%$ or less on echocardiography [1]. In recent years, researchers have focused on the comorbidity of CHF.

Anemia as a manifest form of ID is a frequent finding in adults with CHF [2]. The incidence of anemia appears to grow with increase in functional class (FC) of chronic heart failure according to NYHA classification - at FC III to $33 \%$ and at FC IV to $80 \%$ [3, 4]. An important clinical aspect is that iron deficiency anemia (IDA), except sideropenic syndrome, manifests with nonspecific symptoms. Symptoms such as dyspnea and fatigue may be difficult to distinguish from symptoms of HF. Therefore, it can be diagnosed only by determining the laboratory parameters while the anemia syndrome during CHF is associated with an increase in mortality and the frequency of hospitalizations of patients $[5,6,7]$. 
Correction of anemia in $\mathrm{CHF}$ is important to improve subjective, functional treatment outcomes and to optimize long-term prognosis [8]. According to modern approaches to correction of IDA of patients with CHF peroral and parenteral ferrocorrection are the most often used ones. Several studies have been conducted to determine which ferrocorrection method is better.

Analysis of intravenous iron effectiveness in patients with HF and ID showed an increase of the 6-minute walk test distance and of numerous secondary points related to functional capacity [9]. However, it remained unclear whether such improvements could be obtained with a much easier to administer, more readily available, and less expensive oral iron formulation.

The IRONOUT-HF trial investigated whether oral, rather than intravenous, iron supplementation could improve peak exercise capacity in patients with CHF with reduced LVEF and ID. Contrary to the supportive findings above, no significant change was seen in the point of change in peak oxygen uptake or change in 6-minute walk and quality of life. Also, little change was evident in the indices of iron stores over the course of the study, with only a $3 \%$ increase in transferrin saturation (TS) and an $11 \mathrm{ng} / \mathrm{mL}$ increase in ferritin. The intravenous trials resulted in a 4-fold greater increase in TS and a 20-fold greater increase in ferritin [9]. Of note, in all the trials discussed below, iron deficiency was diagnosed in the setting of heart failure as ferritin less than $100 \mathrm{ng} / \mathrm{mL}$ (absolute iron deficiency) or as ferritin 100 to $300 \mathrm{ng} / \mathrm{mL}$ with transferrin saturation less than $20 \%$ (relative deficiency) [10].

In our opinion for the effective treatment of patients with CHF and iron deficiency with anemic syndrome, it is necessary to differentiate the variant of iron metabolism. IDA is caused by the multifactorial depletion of iron in the body and the main way of its correction is the use of oral or intravenous iron. Hepcidin function to block intestinal iron absorption and iron release from the mononuclear-phagocyte system, which occur due to activation of proinflammatory cytokines, have an impact on the development of ACD as a functional ID. Therefore, the use of oral iron supplements in this type of ID is not effective and, moreover, dangerous due to possible occurrence of hemosiderosis [11].

Futhermore, the modern pharmacological strategy for the treatment of patients with CHF and IDA, except iron preparations, must take into account the use of agents that have antihypoxic, antioxidant and membrane-stabilizing effects, and at the same time regulatory effect on the metabolism of physiologically active compounds to improve the condition of patients.

The purpose of the study is to evaluate the effectiveness of IDA correction, identify and compare the effect of oral ferrotherapy and combined use of ferrotherapy with L-carnitine on clinical and instrumental parameters of patients with CHF with reduced LVEF as possible variants additional therapy to standard treatment.

Material and methods. 62 patients with CHF with reduced LVEF due to hypertensive and ischemic heart disease, FC II-III according to NYHA were examined. All patients had differentiated IDA. There were $72.6 \%$ males and $27.4 \%$ females; and the mean age was $70.0 \pm 0.9$ years.

Number of red blood cells (Rbc), hemoglobin (Hb) level, color index (CI), hematocrit (Hct), serum iron (SI), TS, 6-minute walk stress test, MLHFQ questionnaire and LV morpho-functional parameters by echocardiography were determined.

Only patients with absolute ID and anemic syndrome - IDA were included in the study.

For the diagnosis of IDA, the following criteria were used: 1) laboratory signs of anemia - a decrease $\mathrm{Hgb}$ level in men $<130 \mathrm{~g} / \mathrm{l}$ and in women $<120 \mathrm{~g} / \mathrm{l} ; 2$ ) a decrease in SI in women <11.5 $\mu \mathrm{mol} / 1$ and in men $<13.0 \mu \mathrm{mol} / \mathrm{l} ; 3$ ) ferritin level $<100 \mathrm{ng} / \mathrm{ml}$. Only patients with mild and moderate anemia were included in the study.

All patients received standard therapy indicated by modern ESC recommendations, taking into account ischemic and hypertensive etiology of CHF and comorbid conditions.

The patients were divided in two groups: in addition to the standard therapy, the patients in the 1st group ( $\mathrm{n}=32$ ) were prescribed oral ferrous sulfate in a dose of $320 \mathrm{mg}$, equivalent to $100 \mathrm{mg}$ of bivalent iron and $60 \mathrm{mg}$ of ascorbic acid 2 tablets per day for 6 months; the patients in the 2nd group $(n=30)$ received the standard therapy of CHF and not only iron, but also L-carnitine.

The groups of patients were compared by main clinical characteristics.

Statistical processing of the obtained results was performed using the software package Microsoft Office Excel and Statistica. The obtained measurements are presented as a median (lower, upper quartile). The statistical significance of the difference in the measured parameters was calculated according to Kruskal-Wallis ANOVA \& Median test for all groups criterion and to Wilcoxon matched pairs test criterion. The difference was considered reliable at $p<0.05$.

Research results. Table 1 presents the laboratory and instrumental parameters after treatment of patients. It was found that the use of two variants of ferrocorrection as an application to standard CHF 
treatment among the total number of patients with IDA testified to a sufficient effect both to eliminate signs of anemia and to eliminate ID. Comparison of the studied laboratory parameters of patients with different options for additional treatment after 6 months revealed no difference in the increase in parameters.

Also no difference in the dynamics of myocardium morpho-functional indices between two groups over 6 months of observation was detected.

However, patients with ferrotherapy and L-carnitine had the tendency to more positive dynamics of ECHO-CG parameters - EDD (end-diastolic dimension) decreased by $6.6 \%(\mathrm{p}<0.0001)$, EDV (end-diastolic volume) by $14.1 \%$ ( $\mathrm{p}<0.0001)$, ESD (end-systolic dimension) by $6 \%(\mathrm{p}<0.0001$ ), ESV (end-systolic volume) by $19.4 \%(\mathrm{p}<0.0001)$ and EF increased by $19.6 \%(\mathrm{p}<0.0001)$. EDD decreased by $5 \%(\mathrm{p}<0.0001)$, EDV by $11.3 \%(\mathrm{p}<0.0001)$, ESD by $4,8 \%(\mathrm{p}<0.0001)$, ESV by $17.1 \%$ $(\mathrm{p}<0.0001)$ and $\mathrm{EF}$ increased by $16.4 \%(\mathrm{p}<0.0001)$ in group of patients with only ferrotherapy.

Analysis of the dynamics of the covered six-minute walk test distance in patients on the background of the standard treatment and additional ferrotherapy over six months demonstrated an increase in the actual distance by $8.9 \%$ (from 249.5 to $372,3 \mathrm{~m}, \mathrm{p}<0,0001$ ). The change of the covered six-minute walk test distance in patients on the background of the standard treatment and additional ferrotherapy with L-carnitine was with more positive dynamics. Thus, as compared to the initial indices over 6 months, the covered distance increased by +19,4\% (from 259 to 304,5 m, p<0,0001).

At the end of the study, it was also found that among all patients, after 6 months of treatment, the level of QOL compared to baseline improved by $14.7 \%$ according to the MLHFQ (from 59 to 51 points, $\mathrm{p}<0.0001$ )

Analysis of the dynamics of QOL in patients with standard treatment and additional ferrotherapy over six months demonstrated the negative change in MLHFQ score by $13.7 \%$ (from 60.5 to 52 points, $\mathrm{p}$ $<0.0001$ ), indicating positive QOL dynamics while the analysis of changes in the level of QOL in patients with IDA which received not only 6-month ferrotherapy but also L-carnitine revealed a greater dynamics of the indicator - a negative increase of $16.2 \%$ (from 59 to 48.9 points, $\mathrm{p}<0,0001$ ).

Table 1. Comparison of laboratory and instrumental parameters of patients with CHF with reduced LVEF and IDA after treatment

\begin{tabular}{|c|c|c|c|c|c|c|}
\hline \multirow{2}{*}{ Parameters } & \multicolumn{3}{|c|}{$\begin{array}{l}\text { 6-month ferrotherapy } \\
\qquad \mathbf{n}=32\end{array}$} & \multicolumn{3}{|c|}{$\begin{array}{c}\text { 6-month ferrotherapy } \\
\text { with L-carnitine } \\
\text { n=30 }\end{array}$} \\
\hline & Initial value & $6^{\text {th }}$ month & $\begin{array}{c}\text { Dynamics, } \\
\%\end{array}$ & Initial value & $6^{\text {th }}$ month & $\underset{\%}{\text { Dynamics, }}$ \\
\hline 1 & 2 & 3 & 4 & 5 & 6 & 7 \\
\hline \multicolumn{7}{|c|}{ Hematological parameters } \\
\hline $\mathrm{Hb}, \mathrm{g} / \mathrm{l}$ & $\begin{array}{c}106.5 \\
(96.5 ; 116.5) \\
\end{array}$ & $\begin{array}{c}138 \\
(131.5 ; 147)^{* *}\end{array}$ & $\begin{array}{c}+28.6 \\
(+25.3 ;+34.5) \\
\end{array}$ & $\begin{array}{c}108 \\
(97 ; 116)\end{array}$ & $\begin{array}{c}141 \\
(134 ; 147)^{* *}\end{array}$ & $\begin{array}{c}+31.6 \\
(+24.8 ;+36.8) \\
\end{array}$ \\
\hline $\begin{array}{l}\text { Rbc, } \\
\times 10^{12} / 1\end{array}$ & $\begin{array}{c}4.25 \\
(3.9 ; 4.48)\end{array}$ & $\begin{array}{c}4.6 \\
(435 ; 4.9)^{* *}\end{array}$ & $\begin{array}{c}+8.9 \% \\
(+3.9 ;+14.6)\end{array}$ & $\begin{array}{c}3.9 \\
(3.87 ; 4.45)\end{array}$ & $\begin{array}{c}4.6 \\
(4.3 ; 4.9)^{* *}\end{array}$ & $\begin{array}{c}+11.5 \\
(+5.6 ;+15.6)\end{array}$ \\
\hline CI & $\begin{array}{c}0.77 \\
(0.70 ; 0.84)\end{array}$ & $\begin{array}{c}0.88 \\
(0.86 ; 0.94)^{* *}\end{array}$ & $\begin{array}{c}+17.6 \\
(+8 ;+22)\end{array}$ & $\begin{array}{c}0.80 \\
(0.7 ; .82)\end{array}$ & $\begin{array}{c}0.91 \\
(0.89 ; 0.95)^{* *}\end{array}$ & $\begin{array}{c}+15.9 \\
(+8.3 ;+22.2)\end{array}$ \\
\hline Het, l/l & $\begin{array}{c}0.32 \\
(0.32 ; 0.36) \\
\end{array}$ & $\begin{array}{c}0.37 \\
(0.35 ; 0.41)^{* *} \\
\end{array}$ & $\begin{array}{c}+12.5 \\
(+9.2 ;+21.5)\end{array}$ & $\begin{array}{c}0.32 \\
(0.31 ; 0.35) \\
\end{array}$ & $\begin{array}{c}0.39 \\
(0.37 ; 0.4)^{* *} \\
\end{array}$ & $\begin{array}{c}+19.6 \\
(+14.1 ;+25) \#\end{array}$ \\
\hline SI, umol/l & $\begin{array}{c}7.9 \\
(6.2 ; 10,3)\end{array}$ & $\begin{array}{c}15.3 \\
(12.9 ; 18)^{* *}\end{array}$ & $\begin{array}{c}+82.6 \\
(+63,6 ; \text { an } \\
\text { increase of } \\
2.1 \text { times }) \\
\end{array}$ & $\begin{array}{c}9.55 \\
(6.4 ; 11,2)\end{array}$ & $\begin{array}{c}16 \\
(13.7 ; 18,4)^{* *}\end{array}$ & $\begin{array}{c}+87.2 \\
(+62.8 ; \text { an } \\
\text { increase of } \\
2.1 \text { times })\end{array}$ \\
\hline $\begin{array}{l}\text { Ferritin, } \\
\text { ng/ml }\end{array}$ & $\begin{array}{c}63 \\
(41 ; 82.5)\end{array}$ & $\begin{array}{c}133.5 \\
(99 ; 179)^{* *}\end{array}$ & $\begin{array}{c}\text { an increase } \\
\text { of } 2.3 \text { times } \\
\text { (+90.4; of } \\
3.2 \text { times) }\end{array}$ & $\begin{array}{c}43.5 \\
(31 ; 76)\end{array}$ & $\begin{array}{c}119 \\
(104 ; 158)^{* *}\end{array}$ & $\begin{array}{c}\text { an increase } \\
\text { of } 2.5 \text { times } \\
\text { (of } 2 ; \text { of } 3.2 \\
\text { times) }\end{array}$ \\
\hline TS, \% & $\begin{array}{c}11.1 \\
(8 ; 13.3)\end{array}$ & $\begin{array}{c}23.7 \\
(17.7 ; 30)^{* *}\end{array}$ & $\begin{array}{c}\text { an increase } \\
\text { of } 2.2 \text { times } \\
(+77.8 ; \text { of } \\
2.8 \text { times }) \\
\end{array}$ & $\begin{array}{c}12.8 \\
(8 ; 15.2)\end{array}$ & $\begin{array}{c}27 \\
(20.4 ; 32.3)^{* *}\end{array}$ & $\begin{array}{c}\text { an increase } \\
\text { of } 2.2 \text { times } \\
\text { (+76.8; of } \\
2.8 \text { times) } \\
\end{array}$ \\
\hline $\begin{array}{l}\text { TIBC, } \\
\text { umol/l }\end{array}$ & $\begin{array}{c}77 \\
(67.5 ; 87.7) \\
\end{array}$ & $\begin{array}{c}65.5 \\
(59 ; 74.5)^{* *} \\
\end{array}$ & $\begin{array}{c}-13.6 \\
(-17.7 ;-7.4) \\
\end{array}$ & $\begin{array}{c}74.1 \\
(68.2 ; 86.5) \\
\end{array}$ & $\begin{array}{c}64.1 \\
(57 ; 69)^{* *} \\
\end{array}$ & $\begin{array}{c}-17.8 \\
(-22.5 ;-7.47) \#\end{array}$ \\
\hline
\end{tabular}


Continuation of table 1 .

\begin{tabular}{|c|c|c|c|c|c|c|}
\hline 1 & 2 & 3 & 4 & 5 & 6 & 7 \\
\hline \multicolumn{7}{|c|}{ Echo-CG indices } \\
\hline EDD, $\mathbf{m m}$ & $\begin{array}{c}59 \\
(55,8 ; 62,9) \\
\end{array}$ & $\begin{array}{c}56,6 \\
(54 ; 59) \\
\end{array}$ & $\begin{array}{c}-5 \\
(-7,4 ;-1,83) \\
\end{array}$ & $\begin{array}{c}61 \\
(59 ; 65) \\
\end{array}$ & $\begin{array}{c}58 \\
(55 ; 60) \\
\end{array}$ & $\begin{array}{c}-6,6 \\
(-7,7 ;-4,0) \\
\end{array}$ \\
\hline ESD, mm & $\begin{array}{c}49,1 \\
(46,3 ; 52,8) \\
\end{array}$ & $\begin{array}{c}47 \\
(44 ; 49) \\
\end{array}$ & $\begin{array}{c}-4,8 \\
(-7,5 ;-2,2)\end{array}$ & $\begin{array}{c}52 \\
(49 ; 54,2) \\
\end{array}$ & $\begin{array}{c}48 \\
(46 ; 50,2)\end{array}$ & $\begin{array}{c}-6,0 \\
(-8,7 ;-4,4)\end{array}$ \\
\hline EDV, ml & $\begin{array}{c}173.2 \\
(152.7 ; 197.7)\end{array}$ & $\begin{array}{c}157.8 \\
(140.6 ; 174.1)\end{array}$ & $\begin{array}{c}-11.3 \\
(-15.6 ;-2.9) \\
\end{array}$ & $\begin{array}{c}186.9 \\
(173.2 ; 216)\end{array}$ & $\begin{array}{c}163.3 \\
(147.4 ; 180) \\
\end{array}$ & $\begin{array}{c}-14.1 \\
(-16.7 ;-4.9) \\
\end{array}$ \\
\hline ESV, ml & $\begin{array}{c}113.3 \\
(101.3 ; 134.5)\end{array}$ & $\begin{array}{c}95.7 \\
(82 ; 107.7) \\
\end{array}$ & $\begin{array}{c}-17.1 \\
(-22 ;-10.6)\end{array}$ & $\begin{array}{c}129.5 \\
(112.8 ; 142.5)\end{array}$ & $\begin{array}{c}101 \\
(86 ; 112)\end{array}$ & $\begin{array}{c}-19.4 \\
(-24.9 ;-14.0)\end{array}$ \\
\hline LVEF, \% & $\begin{array}{c}35.1 \\
(32.6 ; 35.8) \\
\end{array}$ & $\begin{array}{c}40.4 \\
(38.4 ; 42.7)\end{array}$ & $\begin{array}{c}+16.4 \\
(13.4 ; 22)\end{array}$ & $\begin{array}{c}34.7 \\
(33.2 ; 35.7) \\
\end{array}$ & $\begin{array}{c}41.9 \\
(38.7 ; 45.9) \\
\end{array}$ & $\begin{array}{c}+19.6 \\
(14.5 ; 24.2)\end{array}$ \\
\hline \multicolumn{7}{|c|}{ Additional parameters } \\
\hline $\begin{array}{l}\text { 6-minute } \\
\text { walk stress } \\
\text { test, meters }\end{array}$ & $\begin{array}{c}248,5 \\
(212.5 ; 293.5)\end{array}$ & $\begin{array}{c}270 \\
(239 ; 320)\end{array}$ & $\begin{array}{c}+11.8 \\
(1.2 ; 17.4)\end{array}$ & $\begin{array}{c}259 \\
(210 ; 301)\end{array}$ & $\begin{array}{c}304,5 \\
(258 ; 360)\end{array}$ & $\begin{array}{c}+19,4 \\
(12.6 ; 22.7) @\end{array}$ \\
\hline $\begin{array}{l}\text { QOL, } \\
\text { points: } \\
\text { MLHFQ }\end{array}$ & $\begin{array}{c}60.5 \\
(54 ; 66)\end{array}$ & $\begin{array}{c}52 \\
(47 ; 58.5)^{* *}\end{array}$ & $\begin{array}{c}-13.7 \\
(-14.9 ;-8.7)\end{array}$ & $\begin{array}{c}59 \\
(54 ; 63)\end{array}$ & $\begin{array}{c}48.5 \\
(44 ; 55)^{* *}\end{array}$ & $\begin{array}{c}-16.2 \\
(18.5 ;-13.6) \#\end{array}$ \\
\hline
\end{tabular}

Notes: EDD - end-diastolic dimension, EDV - end-diastolic volume, ESD - end-systolic dimension, ESV - end-systolic volume, EF - left ventricular ejection fraction, QOL - quality of life, MLHFQ The Minnesota Living With Heart Failure Questionnaire.

$\langle * » \mathrm{p}<0.01$ when compared with initial values; "**" $\mathrm{p}<0.0001$ when compared with initial values; "\#" p <0.05 when comparing values of different observation groups after treatment;

"@" $\mathrm{p}<0.001$ when comparing values of different observation groups after treatment.

Conclusions. 1. It has been detected that iron deficiency anemia's correction in patients with chronic heart failure, who received combination of standart treatment with ferrotherapy is accompanied by an increase in the level of hematological parameters.

2. Favorable changes in erythropoiesis were accompanied by a positive dynamics of the morphofunctional parameters of the myocardium, the distance during the 6-minute walk test and the quality of life indicators.

3. The use of L-carnitine with oral ferrotherapy is accompanied by a greater increase in exercise tolerance, better hemodynamic effects of therapy and a more significant improvement in quality of life among patients compared with using only iron sulfate ferrocorrection.

\section{REFERENCES}

1. Moayedi Y, Kobulnik J. Chronic heart failure with reduced ejection fraction. CMAJ. 2015 Apr 21; 187(7): 518.

2. Felker GM, Adams KF Jr, Gattis WA, O'Connor CM. Anemia as a risk factor and therapeutic target in heart failure. J Am Coll Cardiol. 2004; 44:959.

3. Іванов ВП, Колесник МО, Колесник ОМ, Іванов СІ. Анемії в ракурсі проблеми хронічної серцевої недостатності: патогенез і лабораторна діагностика. Львівський медичний часопис. 2018; 2 (24), 69-76.

4. Стуклов НИ. Дефицит железа и анемия у болных хронической сердечной недостаточностю. Рац. фармакотерапия в кардиологии. 2017; 3 (5), 651- 660.

5. Anand, I.S., Gupta, P. (2018) Anemia and Iron Deficiency in Heart Failure Current Concepts and Emerging Therapies. Circulation, 138, 80-98. doi: 10.1161/circulationaha.118.030099

6. Anand, I.S. (2008) Anemia and chronic heart failure implications and treatment options. J Am Coll Cardiol, 52, 501-511. doi: 10.1016/j.jacc.2008.04.044.

7. Ivanov VP, Kolesnyk MO. Comparative characteristics of quality of life indicators in patients with chronic heart failure with reduced left ventricular ejection fraction depending on iron deficiency type. Eastern Ukrainian Medical Journal. 2019; 3 (7), 246-256.

8. Срмак ОС, Кравчун ПГ, Риндіна НГ, Ринчак ПІ, Титова ГЮ. Терапевтична корекція анемії у хворих iз хронічною серцевою недостатністю ішемічного генезу препаратами заліза в комбінації 3 кверцетином. Запорожский медицинский журнал. 2017; 5 (104): 570-576.

9. Haselhuhn LR, Brotman DJ, Wittstein IS. Heart failure guidelines: What you need to know about the 2017 focused update. Cleveland clinic journal of medicine. 2019; 2 (86): 123- 139. doi:10.3949/ccjm.86a.18022

10. Drozd M, Jankowska EA, Banasiak W, Ponikowski P. Iron therapy in patients with heart failure and iron deficiency: review of iron preparations for practitioners. Am J Cardiovasc Drugs. 2017; 17(3):183-201. doi:10.1007/s40256-016-0211-2

11. Воронков ЛГ. Анемия у пациента с ХСН: как оценивать и как лечить? Серцева недостатність. 2015; 2: 5-15 